\title{
Pattern of Occurrence of Gastrointestinal Strongylosis in an Organized Caprine Farm of Wayanad district, Kerala, South India
}

\section{Karthika Sanalkumar, Anu Adathil Purayil, Praseetha Rajan, Deepa Chundayil Kalarikkal, Priya Manakkulamparambil Narayanan and Reghu Ravindran*}

\author{
Department of Veterinary Parasitology, College of Veterinary and Animal Sciences, \\ Pookode, Wayanad, Kerala-673576 India \\ *Corresponding author:
}

\begin{tabular}{|c|c|}
\hline & A B S T R A C T \\
\hline Keywords & \multirow{4}{*}{$\begin{array}{l}\text { The present study was undertaken to assess the seasonal influence on the } \\
\text { occurrence of gastrointestinal nematode diseases in an organized farm of } \\
\text { Wayanad district of Kerala. Strongylosis was the most predominant } \\
\text { gastrointestinal nematode followed by trichurosis and amphistomosis. } \\
\text { Haemonchosis was the predominant strongyle infection in the farm. The } \\
\text { first peak of eggs (strongyle) per gram of faeces (EPG) in adult goats was } \\
\text { observed during the month of April. In kids, the first peak of EPG was } \\
\text { observed during the period January- February. The second peak of EPG for } \\
\text { strongyle worms in adult goats and kids occurred during October. }\end{array}$} \\
\hline $\begin{array}{l}\text { Egg per Gram, } \\
\text { EPG, Gastro } \\
\text { intestinal } \\
\text { nematodosis, } \\
\text { Strongylosis, }\end{array}$ & \\
\hline Article Info & \\
\hline $\begin{array}{l}\text { Accepted: } \\
\text { 20 January } 2017 \\
\text { Available Online: } \\
\text { 10 February } 2017\end{array}$ & \\
\hline
\end{tabular}

\section{Introduction}

The small ruminant production is very important source of livelihood to the rural people of India. Parasitic infections of sheep and goats are factors responsible for economic losses, reduction in productivity and increased mortality (Sutar et al., 2010). Variations in the incidences of gastrointestinal nematodosis in goats during different seasons were reported from different areas of India (Patnaik et al., 1973; Misra et al., 1974, Ahamad and Ansari, 1987; Swankar et al., 1996, Makhdoomi et al., 1995; Nasreen et al., 2005; Yadav et al., 2006). Wayanad, a region of the Western Ghats, lying at an altitude of 800-1200 feet above mean sea level, enjoys a mild subtropical climate. Most of the farmers in this district depend on livestock farming for their livelihood. The goat population of Wayanad district is 35,150 (Livestock Census, 2012).

Based on available literature, reports on the influence of different seasons on the occurrence of gastrointestinal nematodosis in goats of Wayanad district are scarce. Thus, the present study was undertaken to assess the seasonal influence on the occurrence of gastrointestinal nematode diseases in an organized farm of Wayanad district of Kerala. 


\section{Materials and Methods}

The study consisted of collection of faecal samples randomly from 15 adult goats and 15 kids from Instructional goat farm, College of Veterinary and Animal Sciences, Pookode, Wayanad. Faecal samples were collected every month for a period of one year (November, 2012 to October, 2013). The samples were processed through sedimentation by centrifugation. Positive samples were separated and egg per gram (EPG) of each sample was determined (Soulsby, 1982). Faecal culture was performed to identify the predominant nematode parasite.

\section{Results and Discussion}

In the present study, it was observed that strongylosis was the most predominant parasitic disease in goats, irrespective of the age group (Table 1) followed by trichurosis and amphistomosis. Haemonchosis was the predominant strongyle infection in the farm. There were two peaks of EPG for strongylosis in adult goats and kids during the period of one year (Fig. 1). The first peak in adult goats was during the months of April $(\mathrm{EPG}=593)$ and the second peak of EPG in adult goats was during October $(\mathrm{EPG}=790)$. The first peak of EPG in kids was observed during January to February, 2013 and second peak during June to October.

The high faecal egg counts of strongyles might be largely due to Haemonchus contortus as $H$. contortus was considered as the major cause of parasitic gastroenteritis in sheep and goats in different parts of India (Thaper, 1956; Patnaik et al., 1973; Dhar et al., 1982). Moreover, H. contortus is considered more prolific egg producer (Hunter and Heath, 1984). The high humidity (> 96 per cent) along with high temperature $\left(31^{\circ} \mathrm{C}\right)$ in the month April might have favored the occurrence of strongylosis.

Table.1 Effect of temperature, humidity and rainfall on presence of ova in the faecal sample and average egg per gram (EPG) of adult goats and kids

\begin{tabular}{|c|c|c|c|c|c|c|c|c|c|c|c|c|c|}
\hline \multirow{2}{*}{ Month } & \multirow{2}{*}{$\begin{array}{c}\text { Temp. } \\
\left({ }^{0} \mathrm{c}\right)\end{array}$} & \multirow{2}{*}{$\begin{array}{c}\text { Hum. } \\
(\%)\end{array}$} & \multirow{2}{*}{$\begin{array}{l}\text { Rainfall } \\
(\mathrm{cm})\end{array}$} & \multicolumn{2}{|c|}{ Adult } & \multicolumn{2}{|c|}{ Kids } & \multicolumn{3}{|c|}{$\begin{array}{l}\text { EPG (Adults } \\
\text { goats) }\end{array}$} & \multicolumn{3}{|c|}{ EPG (Kids) } \\
\hline & & & & $\mathrm{E}$ & $\mathrm{P}$ & $\mathrm{E}$ & $\mathrm{P}$ & $S$ & $\mathrm{~T}$ & $\mathrm{~A}$ & $\mathrm{~S}$ & $\mathrm{~T}$ & $\mathrm{~A}$ \\
\hline November-2012 & 16.62 & 92.00 & 124.40 & 15 & 9 & 15 & 4 & 20 & 6 & 13 & 53 & - & - \\
\hline December-2012 & 22.83 & 91.16 & 9.00 & 15 & 10 & 15 & 5 & 133 & - & 6 & 60 & - & - \\
\hline January- 2013 & 29.43 & 93.94 & 0 & 15 & 13 & 15 & 9 & 187 & - & - & 107 & - & - \\
\hline February- 2013 & 29.98 & 95.32 & 7.60 & 15 & 15 & 15 & 15 & 353 & 13 & 13 & 427 & - & - \\
\hline March-2013 & 30.33 & 94.16 & 139.00 & 15 & 7 & 15 & 4 & 93 & & 13 & 20 & - & 13 \\
\hline April-2013 & 31.00 & 96.33 & 77.60 & 15 & 15 & 15 & 15 & 593 & 33 & - & 47 & 40 & - \\
\hline May-2013 & 29.81 & 95.45 & 91.40 & 15 & 0 & 15 & 0 & 0 & - & - & - & - & - \\
\hline June-2013 & 24.08 & 96.33 & 646.20 & 15 & 9 & 15 & 10 & 160 & 6 & - & 160 & - & - \\
\hline July- 2013 & 23.81 & 96.68 & 626.40 & 15 & 6 & 15 & 1 & 53 & - & - & - & - & 6 \\
\hline August- 2013 & 25.50 & 95.84 & 286.60 & 15 & 8 & 15 & 5 & 153 & - & - & 53 & - & - \\
\hline September -2013 & 26.03 & 96.10 & 193.40 & 15 & 11 & 15 & 10 & 173 & 13 & - & 106 & - & - \\
\hline October-2013 & 26.60 & 95.74 & 156.00 & 15 & 12 & 15 & 10 & 790 & & 6 & 120 & - & - \\
\hline
\end{tabular}

Temp. - Average maximum temperature, Hum.- Average maximum humidity, EPG- Average eggs per gram of faeces, E- Total number of samples examined, P- No of samples positive, S- Strongyle ova, T- Trichuris ova, AAmphistome ova 
Table.2 Deworming practices followed in the instructional goat farm, Pookode during November, 2012 to October, 2013

\begin{tabular}{|c|c|c|c|}
\hline Sl.No & Date of deworming & Drug & Dose and route \\
\hline 1 & $12-02-2013$ & Ivermectin & $\begin{array}{c}200 \mu \mathrm{g} / \mathrm{kg} \text { Body weight, } \\
\text { Subcutaneous injection }\end{array}$ \\
\hline 2 & $20-04-2013$ & Fenbendazole & $\begin{array}{c}7.5 \mathrm{mg} / \mathrm{kg} \text { Body weight, } \\
\text { orally }\end{array}$ \\
\hline 3 & $30-05-2013$ & Albendazole & $\begin{array}{c}10 \mathrm{mg} / \mathrm{kg} \text { Body weight, } \\
\text { orally }\end{array}$ \\
\hline 4 & $25-07-2013$ & Fenbendazole & $\begin{array}{c}7.5 \mathrm{mg} / \mathrm{kg} \text { Body weight, } \\
\text { orally }\end{array}$ \\
\hline 5 & $08-09-2013$ & Ivermectin & $\begin{array}{c}200 \mu \mathrm{g} / \mathrm{kg} \text { Body weight, } \\
\text { Subcutaneous injection }\end{array}$ \\
\hline
\end{tabular}

Figure.1 Pattern of EPG for strongyles in kids and adult goats

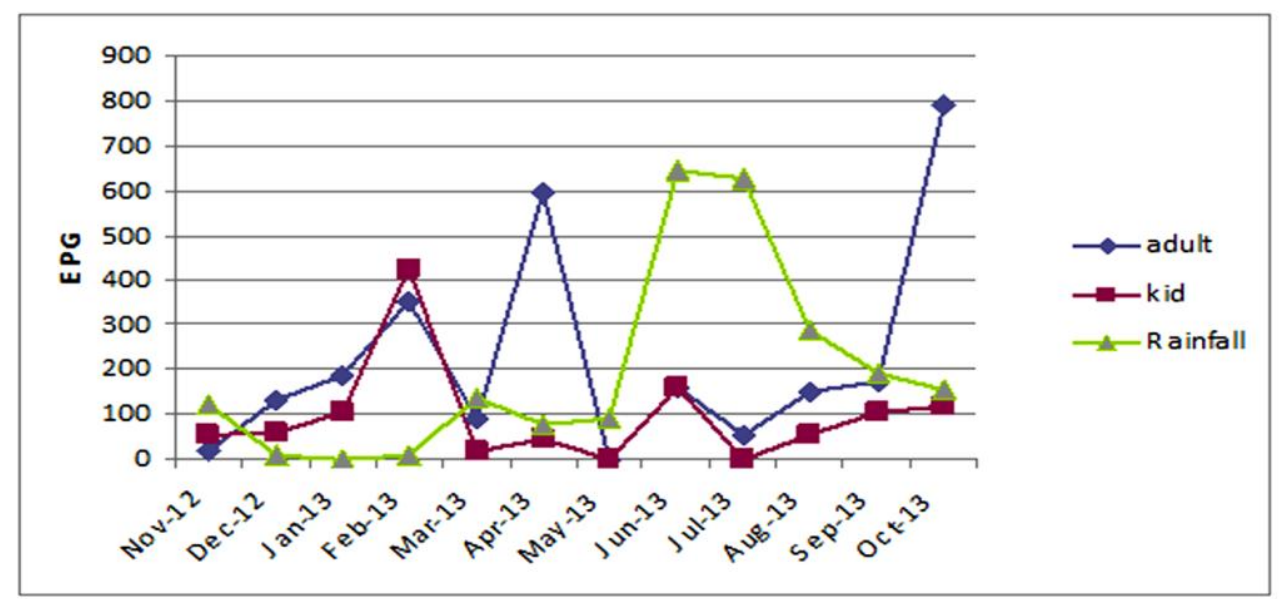

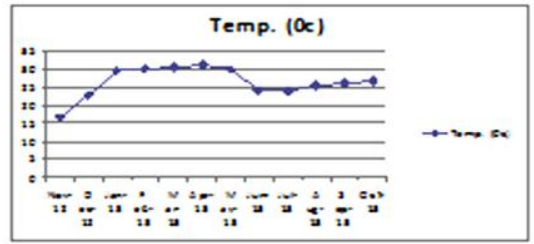

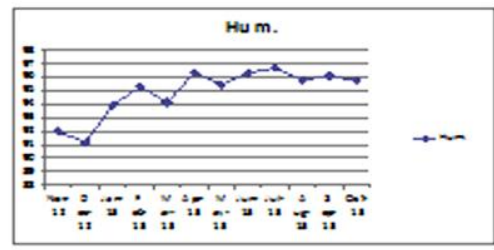

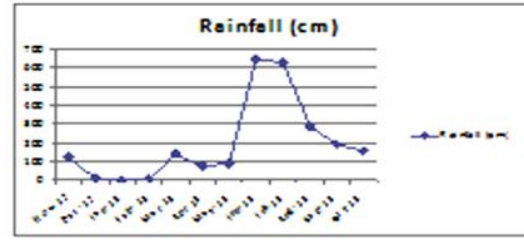

The summer rains (of March) helped in the increase of humidity and thereby the establishment of this peak of EPG. It was observed that the atmospheric temperature slowly increased during the months from June to October which helped in development of hot humid climatic conditions ideal for the survival of larval stages of nematodes.
Lowered resistance of the young ones during January to February might have caused the first peak of EPG in kids. It is clear that the summer rains (during the month of March) and monsoon rains (during the month of JuneJuly), have contributed to the higher EPG in adults and kids. 
It is well documented that gastrointestinal parasitism in grazing animals is directly related to the availability of larvae on pasture and seasonal pasture contamination (Smeal et al., 1980). The warm and humid climate favours the development and survival of preparasitic stages (Durie, 1961). Infection with helminths not only lowers the animal's immunity but it renders susceptible to other pathogenic infections (Garedaghi et al., 2011).

Administration of deworming drugs (three different anthelmintics with two different modes of actions) was done five times in the year in the farm (Table 2) during the study period. Even though ivermectin was administered twice during the course of study; the EPG did not reduce after administration. Hence, benzimidazole group of anthelmintics (Albendazole) may be used for deworming. The frequent and indiscriminate use of anthelmintics may result in development of anthelmintic resistance. Hence, based on the results of the present study, administration of anthelmintics during January-February followed by second administration during the month of August may reduce the worm load; improve productivity and thereby decreasing losses due to deaths.

\section{Acknowledgement}

Financial support from Kerala State Council for Science, Technology and Environment (078/SPS/2012//CSTE) is thankfully acknowledged.

\section{References}

Ahmed, M. and Ansari, J.A. 1987. Prevalence of gastrointestinal nematodes of sheep in Aligarh. Indian Vet. Med. J., 11(3): 165-170.

Dhar, D.N., Sharma, R.L. and Bansal, G.C. 1982. Gastrointestinal nematodes in sheep in Kashmir. Vet. Parasitol., 11(2-3): 271-277.

Durie, P.H. 1961. Parasitic gastro-enteritis of cattle: the distribution and survival of infective strongyle larvae on pasture. Aust. J. Agric. Res., 12(6): 12001211.

Garedaghi, Y., Rezaii Saber, A.P., Naghizadeh A. and Nazeri, M. 2011. Survey on prevalence of sheepand goats lungworms in Tabriz abattoir, Iran. Adv. Environ. Bio., 5(4): 773775.

Hunter, A.G. and Heath, P.J. 1984. Ovine internal parasitism in the Yamen Arab Republic. Trop. Anim. Health Prod., 16(2): 95-106.

Livestock Census, 2012. $19^{\text {th }}$ Livestock census-2012, Ministry of Agriculture, Department of Animal Husbandry, Dairying and Fisheries, Krishi bhawan, New Delhi.

Makhdoomi, D.M., Nasreen, S., Banday, S. D. and Moulvi, B. A. 1995. Incidence of different ovine gastrointestinal parasites in Kashmir. Indian Vet. J., 72: 898-900

Misra, S.C., Das, D.N. and Mohapatra, G.S. 1974. Seasonal distribution of gastrointestinal helminths in sheep of Orissa. Indian J. Anim. Health., 13(1): 25-28.

Nasreen, S., Jeelani, S.G. and Hakeem, M., 2005. Incidence of gastrointestinal nematodes in sheep in Kashmir valley. J. Vet. Parasitol., 19(1): 27-29.

Patnaik, B., Mathur, P.B. and Pachalag, S.V., 1973. Gastrointestinal helminthiasis in sheep in semiarid zone with particular reference to Rambouillet breed. Gujarat Vet., 7: 38-43.

Smeal, M.G., Fraser, G.C. and Robinson, G.G. 1980. Seasonal changes in the structure of nematodes population of cattle in New South Wales in relation to inhibited larval development. Aust. 
Vet. J., 56(2): 80-86.

Soulsby, E.J.L. 1982. Helminths, arthropods and protozoa of domesticated animals. $7^{\text {th }}$ ed., Bailliere and Tindall, London, pp. 252 .

Sutar, A.U., Kengar, S.B., Patiland, S.S. and Khan, M.R. 2010.Prevalence of Gastrointestinal parasites in goats of Ahmednagar district of Maharastra. Vet. World., 3(10):456-57.

Swarankar, C.P., Singh, D., Srivastva, C.P., Bhagwan, P.S.K. and Dimri, U. 1996.

A retrospective study on ovine gastrointestinal helminthoses under semi arid conditions. J. Vet. Parasitol., 10(1): 15-21.

Thaper, G.S. 1956. Systematic survey of helminth parasites of domesticated animals in India. Indian J. Vet. Sci. Anim. Hus., 26(4): 211-271.

Yadav, A.K., Khajuria, J.K. and Raina, A.K. 2006. Seasonal prevalence of gastrointestinal parasites in sheep and goats of Jammu. J. Vet. Parasitol., 20(1): 65-68.

\section{How to cite this article:}

Karthika Sanalkumar, Anu Adathil Purayil, Praseetha Rajan, Deepa Chundayil Kalarikkal, Priya Manakkulamparambil Narayanan and Reghu Ravindran. 2017. Pattern of Occurrence of Gastrointestinal Strongylosis in an Organized Caprine Farm of Wayanad district, Kerala, South India. Int.J.Curr.Microbiol.App.Sci. 6(2): 1038-1042.

doi: http://dx.doi.org/10.20546/ijcmas.2017.602.116 